TITLE:

\title{
Fabrication of LiCoO2/helical nanocarbon composites and their effect on lithium cell performance
}

\section{$\operatorname{AUTHOR}(\mathrm{S})$ :}

Hirai, Toshiro; Yoshida, Toshihiro; Uno, Yusuke;

Tsujikawa, Tomonobu

\section{CITATION:}

Hirai, Toshiro ... [et al]. Fabrication of LiCoO2/helical nanocarbon composites and their effect on lithium cell performance. Journal of Power Sources 2011, 196(16): 6964-6968

\section{ISSUE DATE:}

2011-08

URL:

http://hdl.handle.net/2433/142515

\section{RIGHT:}

C 2010 Elsevier B.V.; この論文は出版社版でありません。引用の際には 出版社版をご確認ご利用ください。; This is not the published version. Please cite only the published version. 
Fabrication of $\mathrm{LiCoO}_{2} /$ Helical Nanocarbon Composites and Their Effect on Lithium Cell

\section{Performance}

Toshiro Hirai $^{\mathrm{a}, \mathrm{c}, *}$, Toshihiro Yoshida ${ }^{\mathrm{a}}$, Yusuke Uno ${ }^{\mathrm{a}, \mathrm{d}}$, and Tomonobu Tsujikawa ${ }^{\mathrm{b}}$

${ }^{a}$ Department of Mechanical Systems Engineering, Toyama Prefectural University, Imizu-shi,

Toyama-ken 939-0398, Japan

${ }^{\mathrm{b}}$ NTT Facilities, Inc., Toshima-ku, Tokyo 170-0004, Japan

${ }^{\mathrm{c}}$ Present address; SACI, Kyoto University, Nishikyo-ku, Kyoto 615-8520, Japan

${ }^{\mathrm{d}}$ Present address; Chuo Branch, NTT Facilities, Inc., Minato-ku, Tokyo 108-0023, Japan

* Corresponding author

E-mail address: t-hirai@saci.kyoto-u.ac.jp

Fax: +81-75-383-3048

Phone: +81-75-383-3052 


\section{Abstract}

We fabricate $\mathrm{LiCoO}_{2}$ /helical nanocarbon ( $\mathrm{HCN}$ ) composites by forming $\mathrm{HCNs}$ on $\mathrm{LiCoO}_{2}$ on which iron oxides $\left(\mathrm{Fe}_{2} \mathrm{O}_{3}\right.$ or $\left.\mathrm{Fe}_{3} \mathrm{O}_{4}\right)$ are dispersed $\left(\mathrm{LiCoO}_{2}\left(\mathrm{Fe}_{2} \mathrm{O}_{3}\right)\right.$ or $\left.\mathrm{LiCoO}_{2}\left(\mathrm{Fe}_{3} \mathrm{O}_{4}\right)\right)$ as catalysts for HCN formation, and estimate their electrochemical properties. Granular nanocarbons form on $\mathrm{LiCoO}_{2}\left(\mathrm{Fe}_{2} \mathrm{O}_{3}\right)$ and $\mathrm{LiCoO}_{2}\left(\mathrm{Fe}_{3} \mathrm{O}_{4}\right)$ at $350^{\circ} \mathrm{C}$ although $\mathrm{HCNs}$ of about $100 \mathrm{~nm}$ in diameter form on $\mathrm{LiCoO}_{2}\left(\mathrm{Fe}_{2} \mathrm{O}_{3}\right)$ at $450^{\circ} \mathrm{C}$. Transmission electron microscopy and energy dispersive x-ray spectroscopy measurements show that HCNs consist of stacked graphene layers for $\mathrm{LiCoO}_{2}\left(\mathrm{Fe}_{2} \mathrm{O}_{3}\right) / \mathrm{HCN}$ composites fabricated at $450^{\circ} \mathrm{C}$. On the other hand, several-nm-thick tetragonal layer exists on the $\mathrm{LiCoO}_{2}$ substrate and amorphous nanocarbons form on the tetragonal layer for $\mathrm{LiCoO}_{2}\left(\mathrm{Fe}_{2} \mathrm{O}_{3}\right) / \mathrm{HCN}$ and $\mathrm{LiCoO}_{2}\left(\mathrm{Fe}_{3} \mathrm{O}_{4}\right) / \mathrm{HCN}$ composites fabricated at $350^{\circ} \mathrm{C}$. X-ray diffraction measurements suggest that $\mathrm{Fe}_{2} \mathrm{O}_{3}$ and $\mathrm{Fe}_{3} \mathrm{O}_{4}$ do not completely inhibit $\mathrm{LiCoO}_{2}$ decomposition. Cathodes containing $\mathrm{LiCoO}_{2}\left(\mathrm{Fe}_{2} \mathrm{O}_{3}\right) / \mathrm{HCN}$ or $\mathrm{LiCoO}_{2}\left(\mathrm{Fe}_{3} \mathrm{O}_{4}\right) / \mathrm{HCN}$ fabricated at $350^{\circ} \mathrm{C}$ improve rate capability of lithium cells. However, this rate capability is not better than that of cathodes containing a mixture of $\mathrm{LiCoO}_{2}$ and acetylene black. 


\section{Introduction}

High-rate and long-life lithium-ion batteries have long been expected as automotive and next-generation industrial batteries. Cathode active material/carbon composites have been studied as means of prolonging cycle life of such batteries $(1,2)$ as well as cathode active materials have been studied to improve lithium-ion cell capacity and rate capability (3-7).

On the other hand, some researchers have fabricate nanocarbons using chemical vapor deposition (CVD) (8-11). Nanocarbons produced using CVD has a helical shape and are reported to be semimetals with the potential to be superconductive materials (12). This suggests that they have high potential for use as conductive materials for the cathodes of lithium-ion cells. We have fabricated $\mathrm{LiCoO}_{2} /$ helical nanocarbon ( $\mathrm{HCN}$ ) composites and evaluated their electrochemical properties (13). We successfully obtained composites from HCNs formed on a $\mathrm{LiCoO}_{2}$ substrate. However, $\mathrm{LiCoO}_{2}$ severely decomposed and a cell containing $\mathrm{LiCoO}_{2} / \mathrm{HCN}$ composite exhibited a low specific capacity.

We used $\mathrm{Fe}_{2} \mathrm{O}_{3}$ and $\mathrm{Fe}_{3} \mathrm{O}_{4}$ as catalysts to fabricate $\mathrm{LiCoO}_{2} / \mathrm{HCNs}$ effectively without $\mathrm{LiCoO}_{2}$ decomposition at lower temperature to show better performance as cathode active material. We prepared a $\mathrm{LiCoO}_{2}$ substrate on which iron oxides $\left(\mathrm{Fe}_{2} \mathrm{O}_{3}\right.$ or $\left.\mathrm{Fe}_{3} \mathrm{O}_{4}\right)$ were dispersed $\left(\mathrm{LiCoO}_{2}\left(\mathrm{Fe}_{2} \mathrm{O}_{3}\right)\right.$ or $\left.\mathrm{LiCoO}_{2}\left(\mathrm{Fe}_{3} \mathrm{O}_{4}\right)\right)$ as catalysts for $\mathrm{HCN}$ formation. We then formed HCNs on $\mathrm{LiCoO}_{2}\left(\mathrm{Fe}_{2} \mathrm{O}_{3}\right)$ or $\mathrm{LiCoO}_{2}\left(\mathrm{Fe}_{3} \mathrm{O}_{4}\right)$ at $450^{\circ} \mathrm{C}$ or lower and estimated effect of the composites on lithium cell performance. 


\section{Experimental}

We used $\mathrm{LiCoO}_{2}$ (Nippon Chemical Industrial Co., Diameter: $10 \mu \mathrm{m}$ ) as a substrate and $\mathrm{Fe}_{2} \mathrm{O}_{3}$ and $\mathrm{Fe}_{3} \mathrm{O}_{4}$ (Wako Pure Chemical Industries, Ltd.) as catalysts for helical nanocarbon (HCN) formation using chemical vapor deposition (CVD).

We prepared slurries by dispersing $10 \mathrm{~g}$ of $\mathrm{LiCoO}_{2}$ and $0.5 \mathrm{~g}$ of $\mathrm{Fe}_{2} \mathrm{O}_{3}$ or $\mathrm{Fe}_{3} \mathrm{O}_{4}$ into $50 \mathrm{ml}$ of distilled water to uniformly and effectively disperse $\mathrm{Fe}_{2} \mathrm{O}_{3}$ or $\mathrm{Fe}_{3} \mathrm{O}_{4}$ on the surface of $\mathrm{LiCoO}_{2}$ particles and stirred a solution containing the mixture in a beaker overnight on a hot plate at about $80^{\circ} \mathrm{C}$ to evaporate water. The mixture was then dried overnight in a vacuum at $80^{\circ} \mathrm{C}$.

We fabricated the composites by forming $\mathrm{HCNs}$ on the surface of $\mathrm{LiCoO}_{2} / \mathrm{Fe}_{2} \mathrm{O}_{3}$ or $\mathrm{LiCoO} / \mathrm{Fe}_{3} \mathrm{O}_{4}$ powder mounted on a ceramic boat using CVD in a quartz tube and supplied $60 \mathrm{ml}$ $\mathrm{min}^{-1}$ of $\mathrm{C}_{2} \mathrm{H}_{2}$ gas as a carbon source and $50 \mathrm{ml} \mathrm{min}^{-1}$ of $\mathrm{Ar}$ as a carrier at $450^{\circ} \mathrm{C}$ or $350^{\circ} \mathrm{C}$ for 10 $\min$.

We estimated the electrochemical properties of the composites using a lithium cell. We fabricated cathode disks (area, $1.33 \mathrm{~cm}^{2}$ ) by mixing the obtained composites, acetylene black (AB, Denki Kagaku Kogyo Co.) and PTFE powder with a ratio of 70 wt $\%$ of $\mathrm{LiCoO}_{2}, 25$ wt\% of $\mathrm{AB}$ and HCNs formed using CVD, and $5 \mathrm{wt} \%$ of PTFE, and rolling the mixture into a flat sheet. We fabricated CR2032 coin-type cells for evaluating electrochemical properties. Each coin-type cell consisted of a cathode, a lithium anode (Honjo Chemical Co.: area, $1.13 \mathrm{~cm}^{2}$ ) and a $1 \mathrm{M}$ $\mathrm{LiPF}_{6}$-ethylene carbonate/dimethyl carbonate (volume ratio: 1/1) electrolyte (Tomiyama Pure 
Chemicals Co.). Test cells were charged at $0.75 \mathrm{~mA} \mathrm{~cm}^{-2}$ to $4.3 \mathrm{~V}$ and then discharged at constant current to $3.0 \mathrm{~V}$ at $21^{\circ} \mathrm{C}$ after a 10 -min rest.

\section{Results and Discussion}

Figure 1 shows a scanning electron microscope (SEM) image of the $\mathrm{LiCoO}_{2} / \mathrm{HCN}$ composite.

HCNs are formed on the $\mathrm{LiCoO}_{2}$ surface. However, the HCNs are not distributed uniformly and the bare $\mathrm{LiCoO}_{2}$ surface can be seen. HCNs have a helical shape with a diameter of $200 \mathrm{~nm}$ or smaller. We generally observed HCNs with an irregular helical shape. We have not found an optimum fabrication condition of HCNs with a regular helical shape.

Figure 2 shows transmission electron microscope (TEM) photos of the composites fabricated from $\mathrm{HCNs}$ formed on $\mathrm{LiCoO}_{2}$ substrate without iron oxides at $450^{\circ} \mathrm{C}$. HCNs contain many crystalline boundaries of graphene layers and serious turbulence was also observed, indicated with the circle in Fig. 2, which may result in an irregular helical shape of HCNs. We measured contents of the composites by energy dispersive x-ray spectroscopy (EDS). Figure 3 shows areas for EDS measurements as squares. The results are listed in Table 1 . Carbon mainly existed in dark areas 1, 2, 3, and 4 around the white area. On the other hand, white area 5 contained more than $60 \%$ Co, which is larger than the Co percentage of $\mathrm{LiCoO}_{2}$. This suggests that area 5 contained Co and $\mathrm{CoO}$ formed from decomposed $\mathrm{LiCoO}_{2}$.

Furthermore, we used X-ray diffraction (XRD) to estimate the stability of $\mathrm{LiCoO}_{2}$ under our experimental conditions. Figure 4 shows XRD patterns of $\mathrm{LiCoO}_{2} / \mathrm{HCN}$ composites fabricated at 
$450^{\circ} \mathrm{C}$. The XRD contains peaks of $\mathrm{Li}_{2} \mathrm{CO}_{3}, \mathrm{Co}$, and $\mathrm{CoO}$ and no peaks of $\mathrm{LiCoO}_{2}$, which shows that $\mathrm{LiCoO}_{2}$ decomposed without iron oxides. The results coincide with those of EDS measurements.

We then fabricated a composite from HCNs formed on $\mathrm{LiCoO}_{2}$ substrate with $\mathrm{Fe}_{2} \mathrm{O}_{3}$ or $\mathrm{Fe}_{3} \mathrm{O}_{4}$ and estimate its effect on inhibition of $\mathrm{LiCoO}_{2}$ decomposition. Figure 5 shows SEM photo of the composite fabricated with $\mathrm{Fe}_{2} \mathrm{O}_{3}$ at $450^{\circ} \mathrm{C}$. HCNs were successfully formed on $\mathrm{LiCoO}_{2}$ particles and there was no significant difference in the HCN formation from the composites fabricated without iron oxides. We obtained the same results for the composite fabricated with $\mathrm{Fe}_{3} \mathrm{O}_{4}$. On the other hand, we observed nanocarbons were not helical shaped for the composites fabricated at $350^{\circ} \mathrm{C}$ (Fig. 6). "Immature" and particulate HCNs formed on the substrate at $350^{\circ} \mathrm{C}$.

Figure 7 shows TEM photos of the composite fabricated with $\mathrm{Fe}_{2} \mathrm{O}_{3}$ at $350^{\circ} \mathrm{C}$. Figure 7 (a) shows TEM image of the area where there was $\mathrm{Fe}_{2} \mathrm{O}_{3}$, and Fig. 7(b) shows TEM image of the area where there was no $\mathrm{Fe}_{2} \mathrm{O}_{3}$.

By fabricating at $350^{\circ} \mathrm{C}$, amorphous nanocarbons (C in Fig. 7), formed on the $\mathrm{LiCoO}_{2}$ substrate (A in Fig. 7), and there was no significant difference in shape due to the existence of $\mathrm{Fe}_{2} \mathrm{O}_{3}$. We also observed a tetragonal thin layer (B in Fig. 7) on the substrate A. Figure 8 shows TEM photos of the composite fabricated with $\mathrm{Fe}_{3} \mathrm{O}_{4}$ at $350^{\circ} \mathrm{C}$. We observed the same condition for the composite fabricated with $\mathrm{Fe}_{3} \mathrm{O}_{4}$ at $350^{\circ} \mathrm{C}$ shown in both of Fig. 8 (a) and (b) as that for the composite fabricated with $\mathrm{Fe}_{2} \mathrm{O}_{3}$ at $350^{\circ} \mathrm{C}$. 
We observed a tetragonal layer on as-received $\mathrm{LiCoO}_{2}$ particles. We therefore do not conclude that this layer formed using CVD. Kobayashi et al. reported a layer on $\mathrm{Li}(\mathrm{NiCo}) \mathrm{O}_{2}(14)$, which corresponds to what we observed.

Figure 9 shows XRD patterns of $\mathrm{LiCoO}_{2} /$ nanocarbon composites prepared with and without $\mathrm{Fe}_{2} \mathrm{O}_{3} ; \mathrm{LiCoO}_{2}\left(\mathrm{Fe}_{2} \mathrm{O}_{3}\right) / \mathrm{HCN}\left(350^{\circ} \mathrm{C}\right), \mathrm{LiCoO}_{2}\left(\mathrm{Fe}_{2} \mathrm{O}_{3}\right) / \mathrm{HCN}\left(450^{\circ} \mathrm{C}\right)$, and $\mathrm{LiCoO}_{2} / \mathrm{HCN}\left(450^{\circ} \mathrm{C}\right)$. The XRD patterns indicate that $\mathrm{LiCoO}_{2}$ retained its original structure in part but it also suggests that addition of $\mathrm{Fe}_{2} \mathrm{O}_{3}$ did not prevent $\mathrm{LiCoO}_{2}$ from decomposing.

We also measured XRD for $\mathrm{LiCoO}_{2}\left(\mathrm{Fe}_{3} \mathrm{O}_{4}\right) / \mathrm{HCN}$ composite fabricated at $350^{\circ} \mathrm{C}$ and confirmed addition of $\mathrm{Fe}_{3} \mathrm{O}_{4}$ inhibited $\mathrm{LiCoO}_{2}$ decomposition through $\mathrm{HCN}$ fabrication.

We evaluated $\mathrm{LiCoO}_{2}$ decomposition in relation to the addition of $\mathrm{Fe}_{2} \mathrm{O}_{3}$ and $\mathrm{HCN}$ fabrication temperature. Table 2 shows intensity ratios of main peaks of $\mathrm{Li}_{2} \mathrm{CO}_{3}$ (peak $\mathrm{B}$ in Fig. 9), $\mathrm{CoO}$ (peak C in Fig. 9), and Co (peak D in Fig. 9) based on $\mathrm{LiCoO}_{2}$ peak (peak A in Fig. 9). XRD peak intensity ratios indicate that $\mathrm{LiCoO}_{2}$ decomposition was significantly inhibited by coating with $\mathrm{Fe}_{2} \mathrm{O}_{3}$ and that $\mathrm{HCN}$ fabrication temperature decreased.

We estimated the electrochemical properties of $\mathrm{LiCoO}_{2} /$ nanocarbon composites using a lithium cell. Figure 10 shows rate capability of lithium cells containing $\mathrm{LiCoO}_{2}\left(\mathrm{Fe}_{2} \mathrm{O}_{3}\right) / \mathrm{HCN}$ composites, $\mathrm{LiCoO}_{2}\left(\mathrm{Fe}_{2} \mathrm{O}_{3}\right) / \mathrm{HCN}\left(350^{\circ} \mathrm{C}\right)$ and $\mathrm{LiCoO}_{2}\left(\mathrm{Fe}_{2} \mathrm{O}_{3}\right) / \mathrm{HCN}\left(450^{\circ} \mathrm{C}\right)$, compared with that of a lithium cell containing as-received $\mathrm{LiCoO}_{2}$. The cell containing $\mathrm{LiCoO}_{2}\left(\mathrm{Fe}_{2} \mathrm{O}_{3}\right) / \mathrm{HCN}\left(350^{\circ} \mathrm{C}\right)$ showed better rate capability than cell containing $\mathrm{LiCoO}_{2}\left(\mathrm{Fe}_{2} \mathrm{O}_{3}\right) / \mathrm{HCN}\left(450^{\circ} \mathrm{C}\right)$. However, the rate 
capability of our composites is currently inferior to that of as-received $\mathrm{LiCoO}_{2}$. We also estimated the rate capability of a lithium cell containing $\mathrm{LiCoO}_{2}\left(\mathrm{Fe}_{3} \mathrm{O}_{4}\right) / \mathrm{HCN}$ composite $\left(350^{\circ} \mathrm{C}\right)$. The results are shown in Fig. 11 . The $\mathrm{LiCoO}_{2}\left(\mathrm{Fe}_{3} \mathrm{O}_{4}\right) / \mathrm{HCN}\left(350^{\circ} \mathrm{C}\right)$ cell showed the same rate capability as the $\mathrm{LiCoO}_{2}\left(\mathrm{Fe}_{2} \mathrm{O}_{3}\right) / \mathrm{HCN}\left(350^{\circ} \mathrm{C}\right)$ cell. By using iron oxide catalysts and fabricating the composites at lower temperature, $\mathrm{LiCoO}_{2}$ decomposed less and the composites showed better cell performance than that of composites fabricated without the catalysts at higher temperature. The challenge is to fabricate composites with more crystallized HCN for better rate capability of lithium cells than that of the cathode mixed with $\mathrm{LiCoO}_{2}$ and $\mathrm{AB}$. 


\section{Conclusion}

We fabricated $\mathrm{LiCoO}_{2}$ /helical nanocarbon (HCN) composites by forming $\mathrm{HCNs}$ on $\mathrm{LiCoO}_{2}$ on which iron oxides $\left(\mathrm{Fe}_{2} \mathrm{O}_{3}\right.$ or $\left.\mathrm{Fe}_{3} \mathrm{O}_{4}\right)$ were dispersed $\left(\mathrm{LiCoO}_{2}\left(\mathrm{Fe}_{2} \mathrm{O}_{3}\right)\right.$ or $\left.\mathrm{LiCoO}_{2}\left(\mathrm{Fe}_{3} \mathrm{O}_{4}\right)\right)$ as catalysts for HCN formation, and estimated their electrochemical properties.

Cathode active material/nanocarbon composites were fabricated by forming $\mathrm{HCNs}$ on $\mathrm{LiCoO}_{2}$ coated with iron oxides $\left(\mathrm{Fe}_{2} \mathrm{O}_{3}\right.$ or $\left.\mathrm{Fe}_{3} \mathrm{O}_{4}\right)$ to inhibit $\mathrm{LiCoO}_{2}$ degradation. The following results were obtained:

(1) Granular nanocarbons were generated on $\mathrm{LiCoO}_{2}$ with $\mathrm{Fe}_{2} \mathrm{O}_{3}$ and $\mathrm{LiCoO}_{2}$ with $\mathrm{Fe}_{3} \mathrm{O}_{4}$ at $350^{\circ} \mathrm{C}$ although HCNs with about $100 \mathrm{~nm}$ diameter were generated on $\mathrm{LiCoO}_{2}$ with $\mathrm{Fe}_{2} \mathrm{O}_{3}$ at $450^{\circ} \mathrm{C}$.

(2) TEM measurements showed that HCNs consisted of stacked graphene layers for $\mathrm{LiCoO}_{2} / \mathrm{HCN}$ fabricated at $450^{\circ} \mathrm{C}$. On the other hand, several-nm-thick tetragonal layer existed on the $\mathrm{LiCoO}_{2}$ and amorphous nanocarbons formed on the tetragonal layer for $\mathrm{LiCoO}_{2}\left(\mathrm{Fe}_{2} \mathrm{O}_{3}\right) / \mathrm{HCN}$ and $\mathrm{LiCoO}_{2}\left(\mathrm{Fe}_{3} \mathrm{O}_{4}\right) / \mathrm{HCN}$ composites fabricated at $350^{\circ} \mathrm{C}$.

(3) XRD measurements suggested that $\mathrm{Fe}_{2} \mathrm{O}_{3}$ and $\mathrm{Fe}_{3} \mathrm{O}_{4}$ did not completely inhibit $\mathrm{LiCoO}_{2}$ decomposition.

(4) Cathodes containing $\mathrm{LiCoO}_{2}\left(\mathrm{Fe}_{2} \mathrm{O}_{3}\right) / \mathrm{HCN}$ or $\mathrm{LiCoO}_{2}\left(\mathrm{Fe}_{3} \mathrm{O}_{4}\right) / \mathrm{HCN}$ composites fabricated at $350^{\circ} \mathrm{C}$ improved rate capability, but this capability is not as good as that of cathodes containing a mixture of $\mathrm{LiCoO}_{2}$ and $\mathrm{AB}$. 


\section{Acknowledgments}

The authors thank Nippon Chemical Industrial, Co. Ltd. for providing cathode active materials. 


\section{References}

1. H. Huang, S-C. Yin, and L. F. Nazar, Electrochem. Solid-State Lett., 4 (2001) A170.

2. M. Tabuchi, Y. Nabeshima, K. Ado, T. Takeuchi, M. Shikano, H. Kageyama, and K. Tatsumi, Extended Abstract for the 47th Battery Symposium in Japan, Tokyo, 2D19, 2006, pp. 362-363 (in Japanese).

3. T. Ohzuku and Y. Makimura, Chem. Lett., 30 (2001) 642.

4. A. K. Padhi, K. S. Nanjundaswamy, and J. B. Goodenough, J. Electrochem. Soc., 144 (1997) 1188.

5. K. Amine, H. Yasuda, and M. Yamachi, Electrochem. Solid State Lett., 3 (2000) 178.

6. A. Yamada, S. C. Chung, and K. Hinokuma, J. Electrochem. Soc., 148 (2001) A224.

7. A. S. Andersson, J. O. Thomas, B. Kalsa, and L. Haggstroem, Electrochem. Solid-State Lett., 3 (2000) 66.

8. R. T. K. Baker and J. J. Chludzinski, Jr., J. Catal., 64 (1980) 464.

9. S. Amelinckx, X. B. Zhang, D. Bernaerts, X. F. Zhang, V. Ivanov, and J. B. Nagy, Science, 265 (1994) 635.

10. M. Zhang, Y. Nakayama, and L. Pan, Jpn. J. Appl. Phys., 39 (2000) L1242.

11. L. Pan, M. Zhang, and Y. Nakayama, Jpn. J. Appl. Phys., 91 (2002) 10058.

12. K. Akagi, R. Tamura, and M. Tsukada, Phys. Rev. Lett., 74 (1995) 2307.

13. Y. Uno, T. Tsujikawa, and T. Hirai, J. Power Sources, 195 (2010) 354. 
14. H. Kobayashi, M. Shikano, S. Koike, H. Sakaebe, and K. Tatsumi, J. Power Sources, 174 (2007) 380 . 
Table 1 Results of EDS measurements

\begin{tabular}{ccccc}
\hline \multirow{2}{*}{ Area } & \multicolumn{4}{c}{ Amount of atoms (\%) } \\
\cline { 2 - 5 } & C & O & Co & Total \\
\hline 1 & 99.52 & 0.41 & 0.06 & 100.00 \\
3 & 99.04 & 0.74 & 0.22 & 100.00 \\
4 & 89.96 & 5.94 & 4.10 & 100.00 \\
5 & 99.64 & 0.28 & 0.09 & 100.00 \\
& & & & 100.00 \\
\hline
\end{tabular}


Table 2 XRD peak intensity ratio for $\mathrm{LiCoO}_{2} /$ nanocarbon composites

\begin{tabular}{cccc}
\hline Composite & $\mathrm{A} / \mathrm{B}$ & $\mathrm{A} / \mathrm{C}$ & $\mathrm{A} / \mathrm{D}$ \\
\hline $\mathrm{LiCoO}_{2}\left(\mathrm{Fe}_{2} \mathrm{O}_{3}\right) / \mathrm{HCN}\left(350^{\circ} \mathrm{C}\right)$ & 10.37 & 335.8 & 386.7 \\
$\mathrm{LiCoO}_{2}\left(\mathrm{Fe}_{2} \mathrm{O}_{3}\right) / \mathrm{HCN}\left(450^{\circ} \mathrm{C}\right)$ & 11.86 & 4.123 & 17.34 \\
$\mathrm{LiCoO}_{2} / \mathrm{HCN}\left(450^{\circ} \mathrm{C}\right)$ & 1.984 & 1.051 & 0.0313 \\
\hline
\end{tabular}




\section{Figure Captions}

Fig. 1 SEM image of $\mathrm{LiCoO}_{2} / \mathrm{HCN}$ composites fabricated at $450^{\circ} \mathrm{C}$ for $10 \mathrm{~min}$

Fig. 2 TEM image of $\mathrm{LiCoO}_{2} / \mathrm{HCN}$ composite fabricated at $450^{\circ} \mathrm{C}$ for $10 \mathrm{~min}$

Fig. 3 TEM image of $\mathrm{LiCoO}_{2} / \mathrm{HCN}$ composite fabricated at $450^{\circ} \mathrm{C}$ for $10 \mathrm{~min}$, and areas for EDS measurements

Fig. 4 XRD patterns of $\mathrm{LiCoO}_{2} / \mathrm{HCN}\left(450^{\circ} \mathrm{C}\right)$

Fig. 5 SEM photo of $\mathrm{LiCoO}_{2}\left(\mathrm{Fe}_{2} \mathrm{O}_{3}\right) / \mathrm{HCN}$ fabricated at $450^{\circ} \mathrm{C}$

Fig. 6 SEM photo of $\mathrm{LiCoO}_{2}\left(\mathrm{Fe}_{2} \mathrm{O}_{3}\right) /$ nanocarbon fabricated at $350^{\circ} \mathrm{C}$

Fig. 7 TEM images of $\mathrm{LiCoO}_{2}\left(\mathrm{Fe}_{2} \mathrm{O}_{3}\right) /$ nanocarbon composites fabricated at $350^{\circ} \mathrm{C}$ for $10 \mathrm{~min}$.

A: $\mathrm{LiCoO}_{2}$ substrate, B: tetragonal layer, C: nanocarbon fabricated using CVD, and D: deposited Ti layer for TEM measurements

Fig. $8 \mathrm{TEM}$ images of $\mathrm{LiCoO}_{2}\left(\mathrm{Fe}_{3} \mathrm{O}_{4}\right) /$ nanocarbon composites fabricated at $350^{\circ} \mathrm{C}$ for $10 \mathrm{~min}$.

A: $\mathrm{LiCoO}_{2}$ substrate, B: tetragonal layer, C: nanocarbon fabricated by CVD, and D: deposited Ti layer for TEM measurements

Fig. 9 XRD patterns of $\mathrm{LiCoO}_{2} /$ nanocarbon composites fabricated with and without $\mathrm{Fe}_{2} \mathrm{O}_{3}$

Fig. 10 Rate capability of lithium cells containing $\mathrm{LiCoO}_{2}\left(\mathrm{Fe}_{2} \mathrm{O}_{3}\right) / \mathrm{HCN}$ composite and cell containing as-received $\mathrm{LiCoO}_{2}$

Fig. 11 Rate capability of lithium cells containing $\mathrm{LiCoO}_{2}\left(\mathrm{Fe}_{2} \mathrm{O}_{3}\right) / \mathrm{HCN}$ and $\mathrm{LiCoO}_{2}\left(\mathrm{Fe}_{3} \mathrm{O}_{4}\right) / \mathrm{HCN}$ composites fabricated at $350^{\circ} \mathrm{C}$ 
Fig. 1

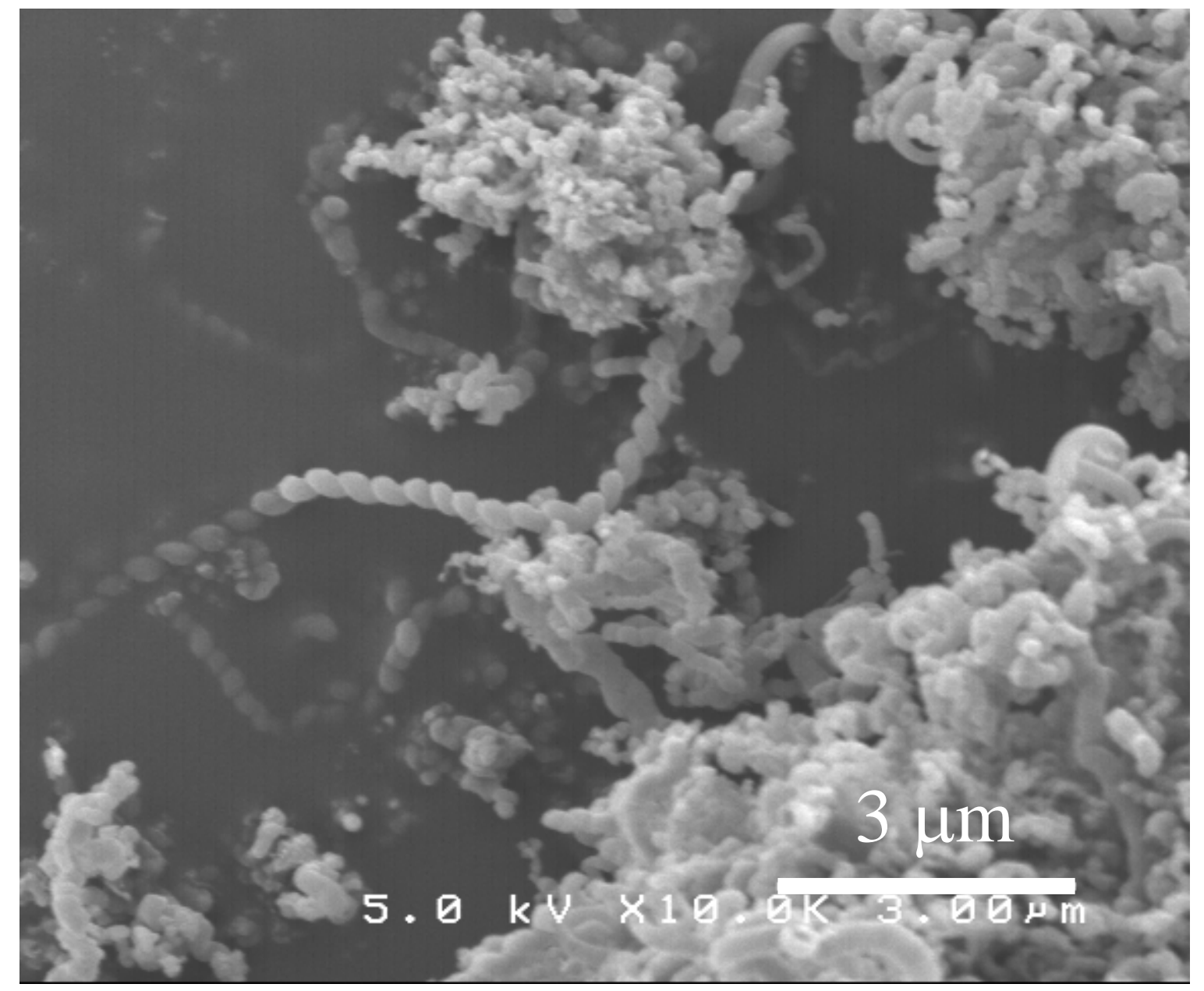


Fig. 2

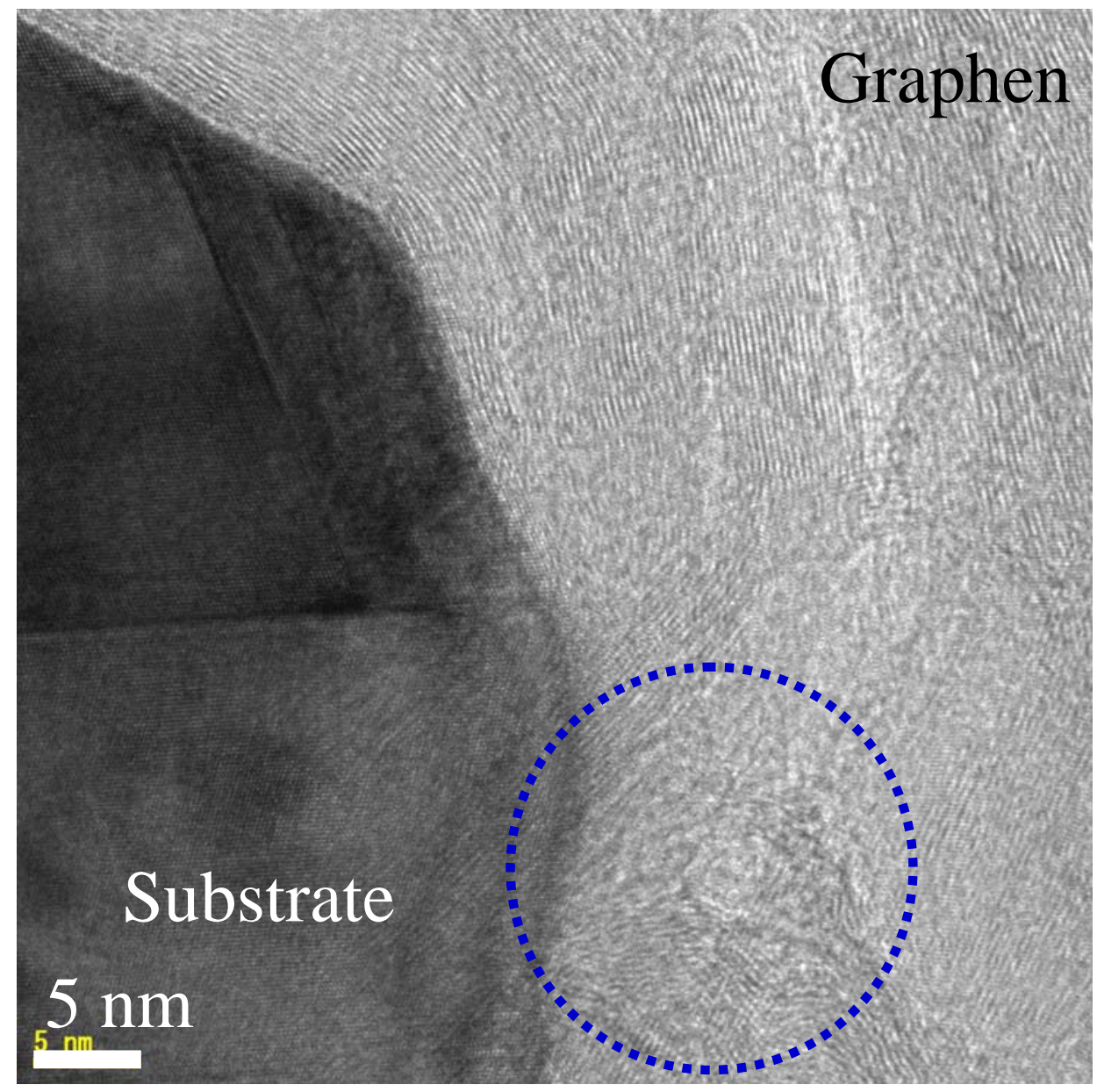


Fig. 3

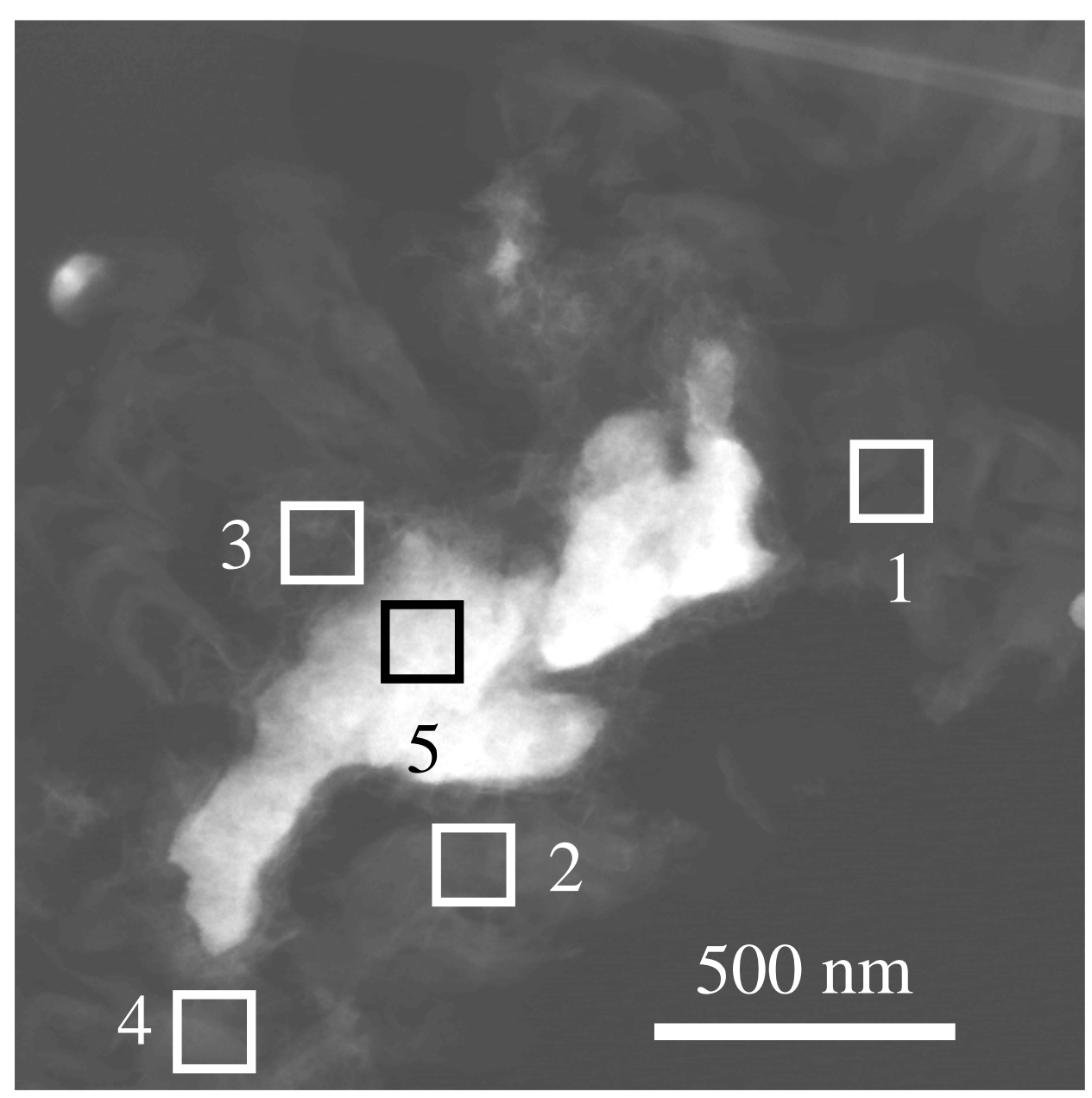


Fig. 4

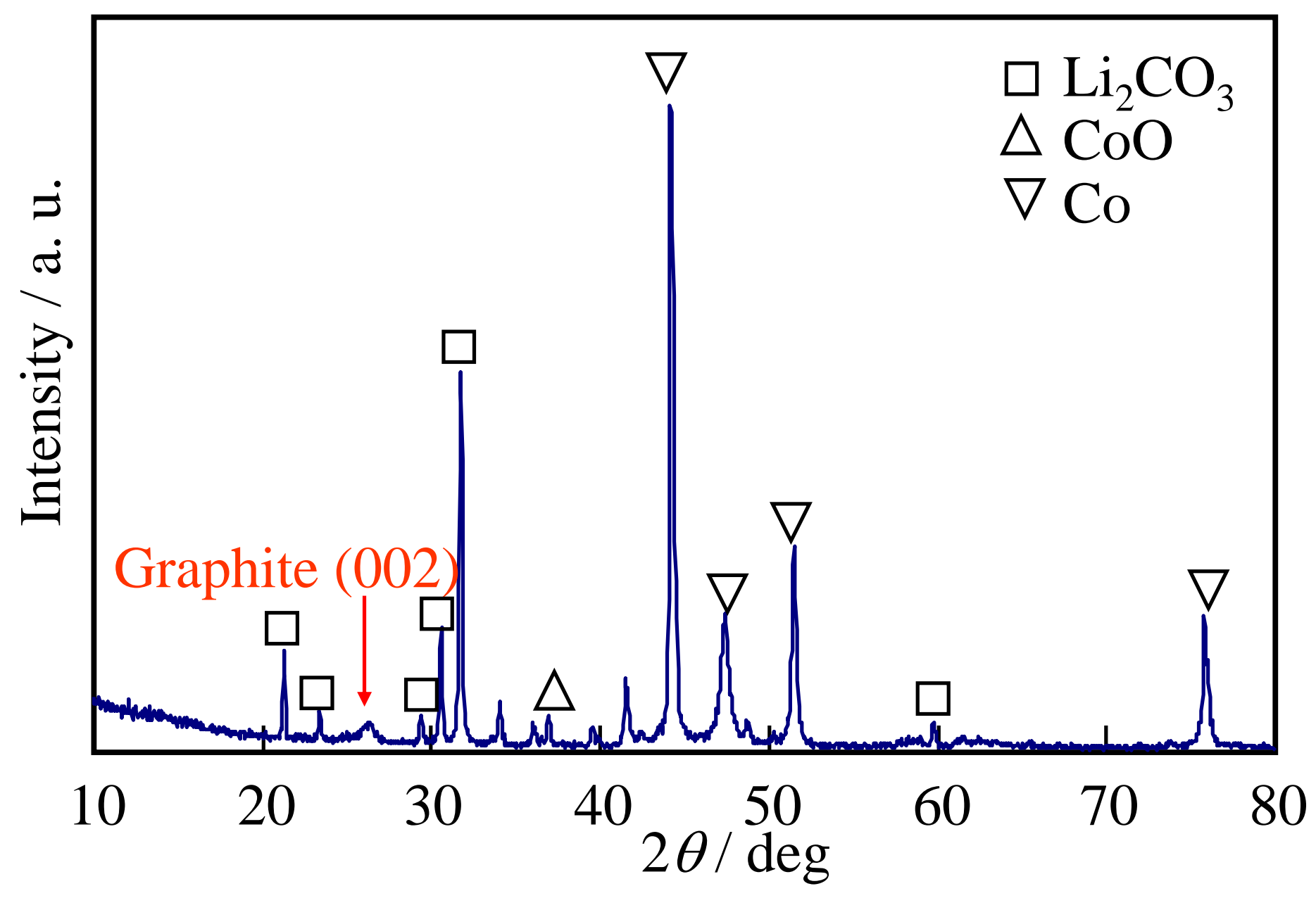


Fig. 5

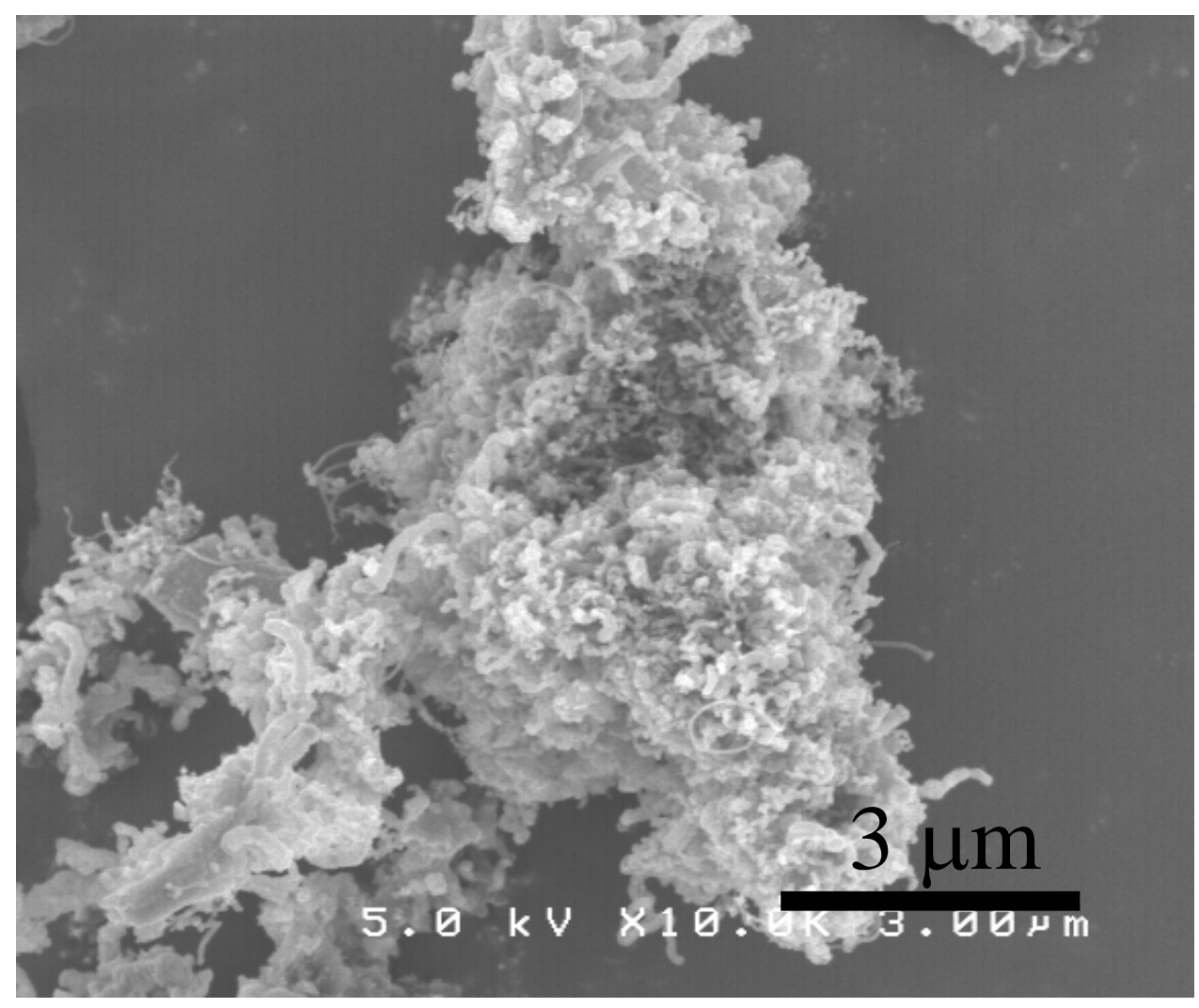


Fig. 6

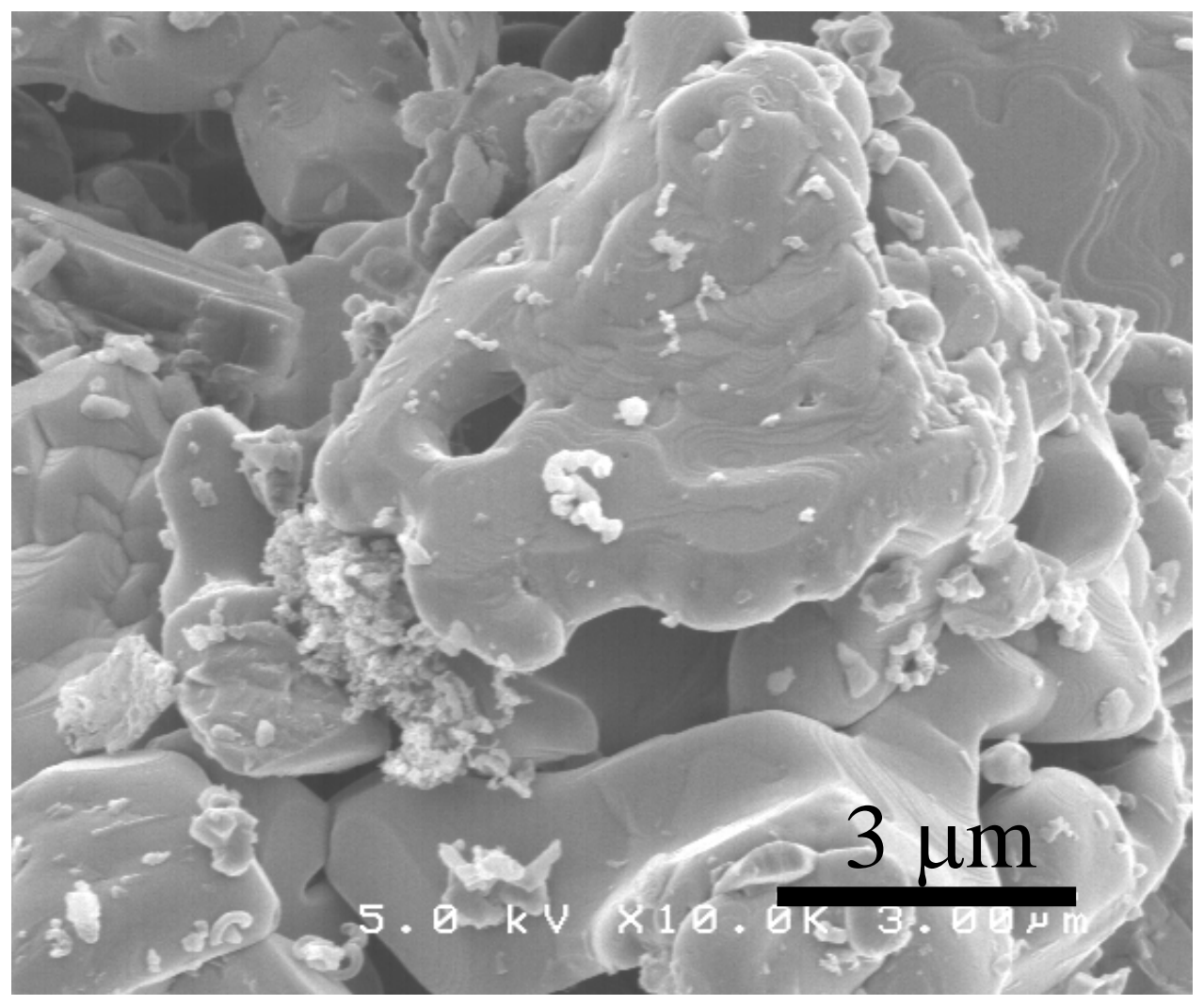


Fig. 7

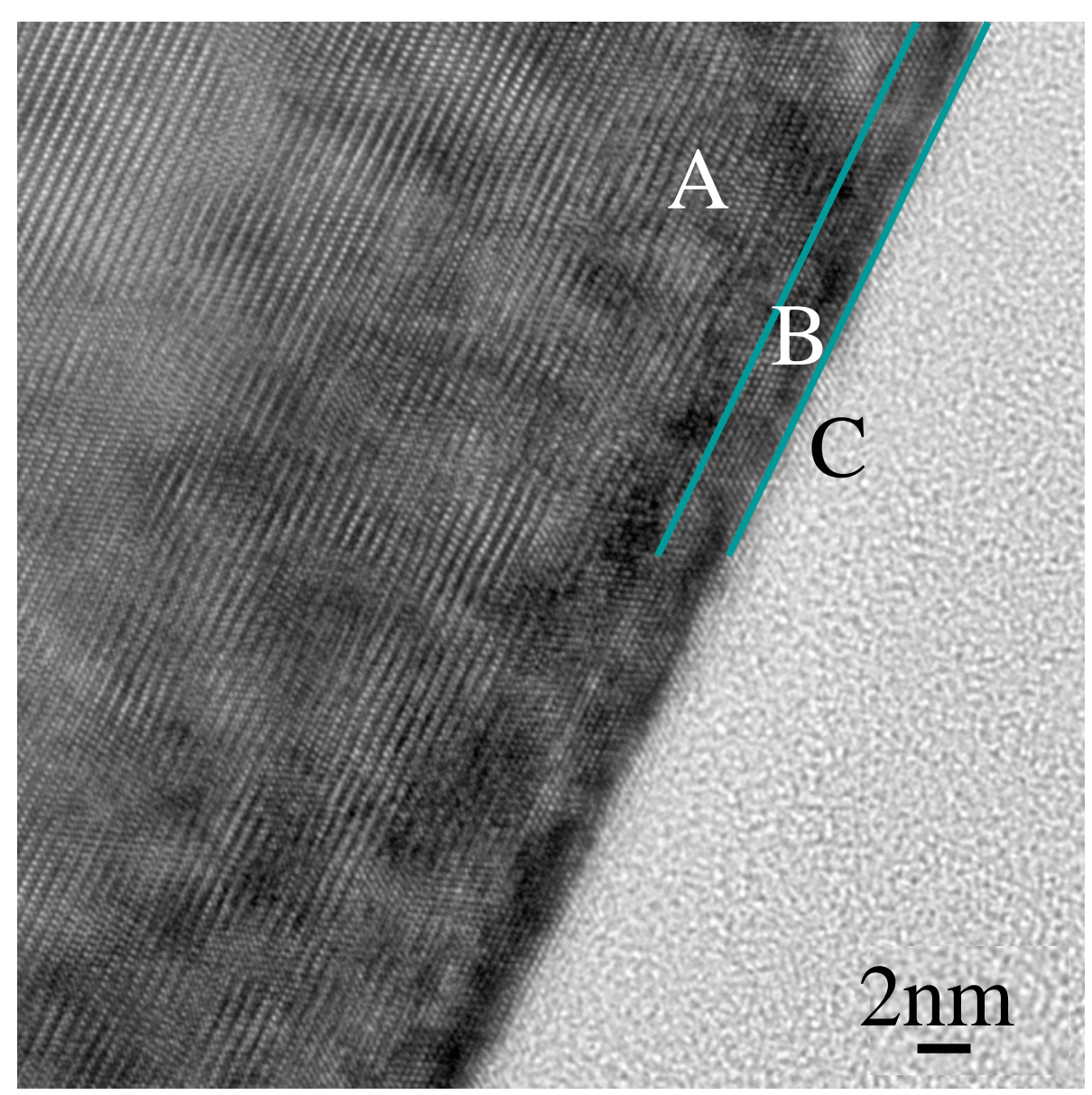

(a)

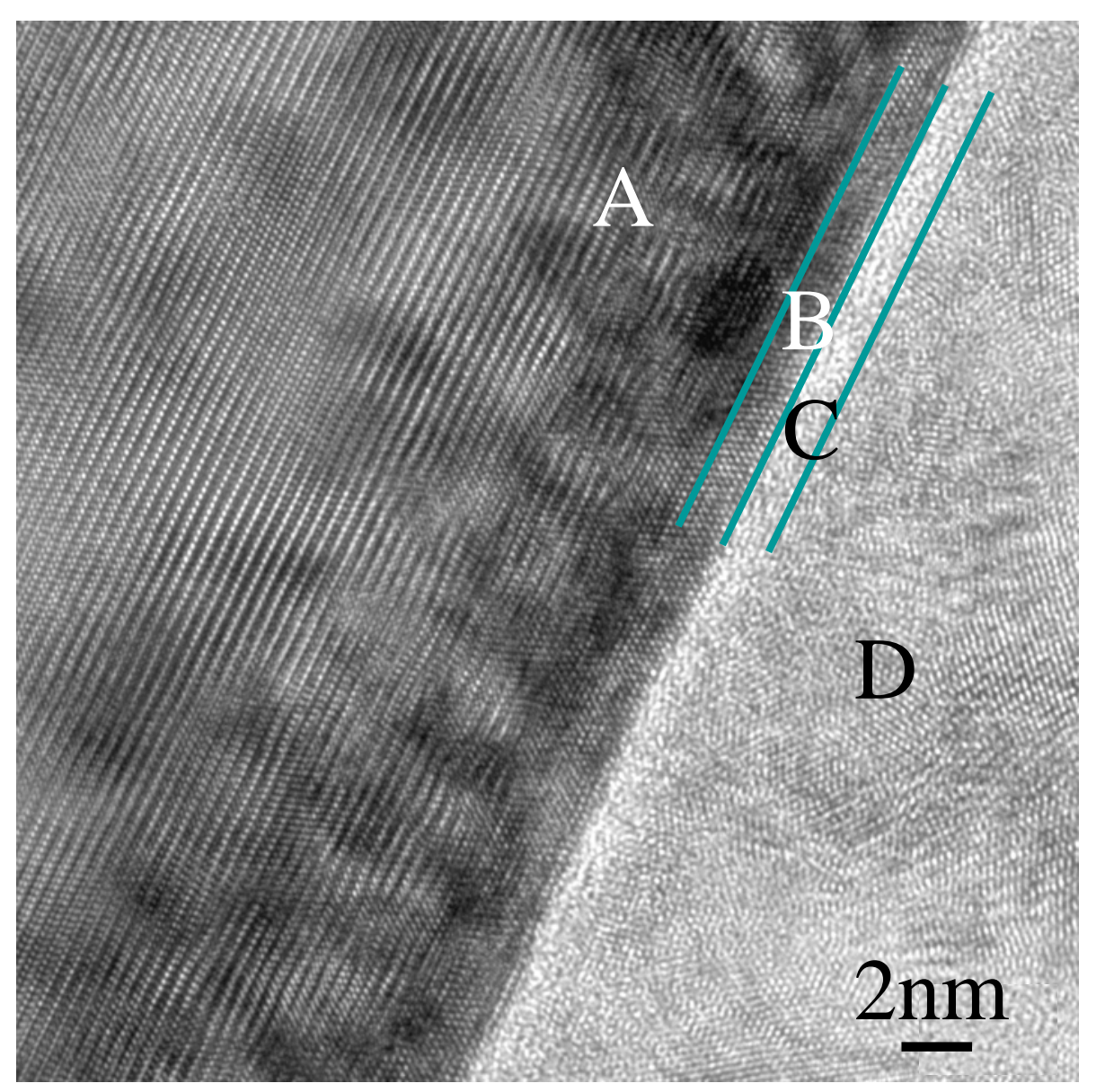

(b) 
Fig. 8

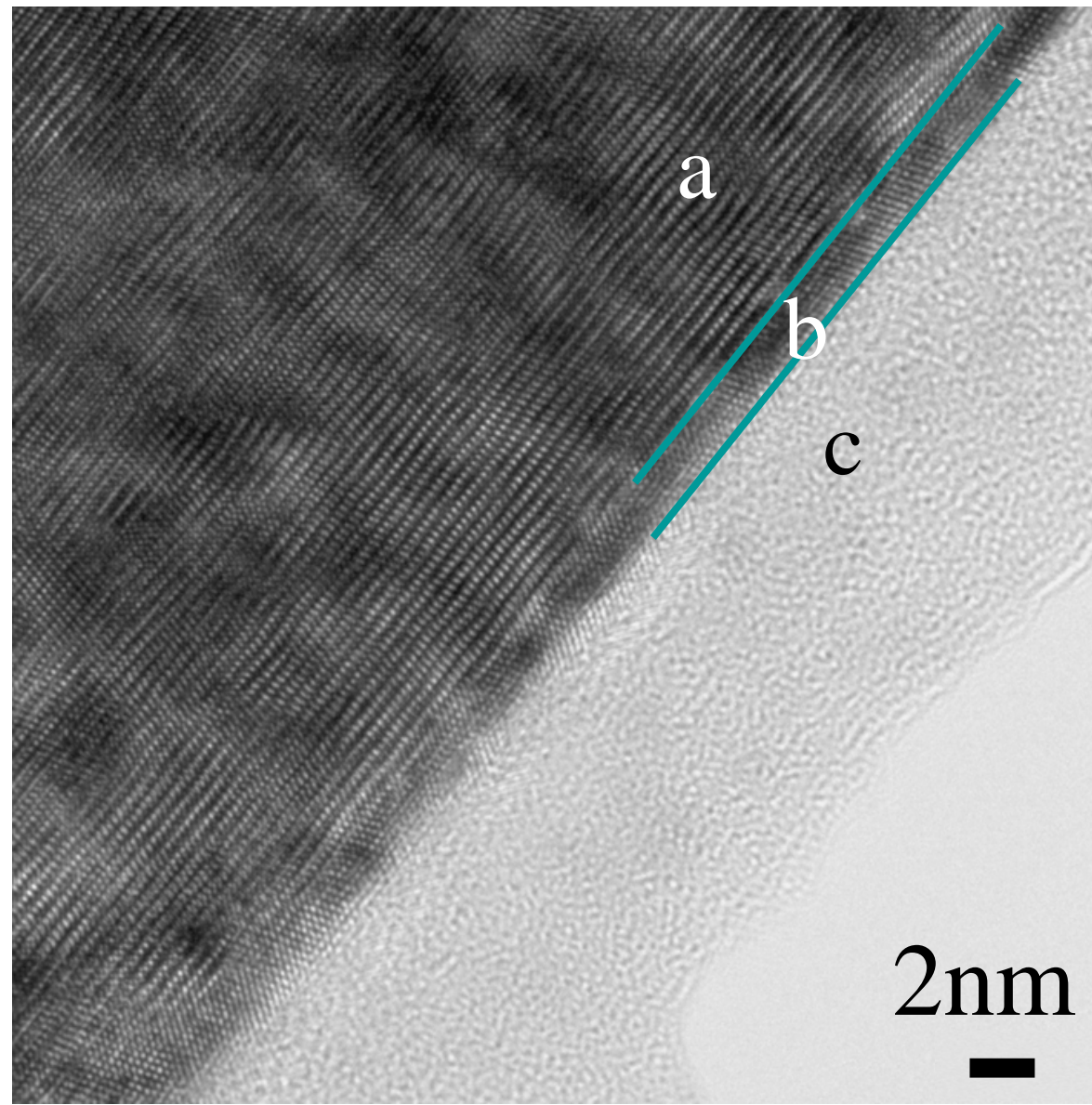

(a)

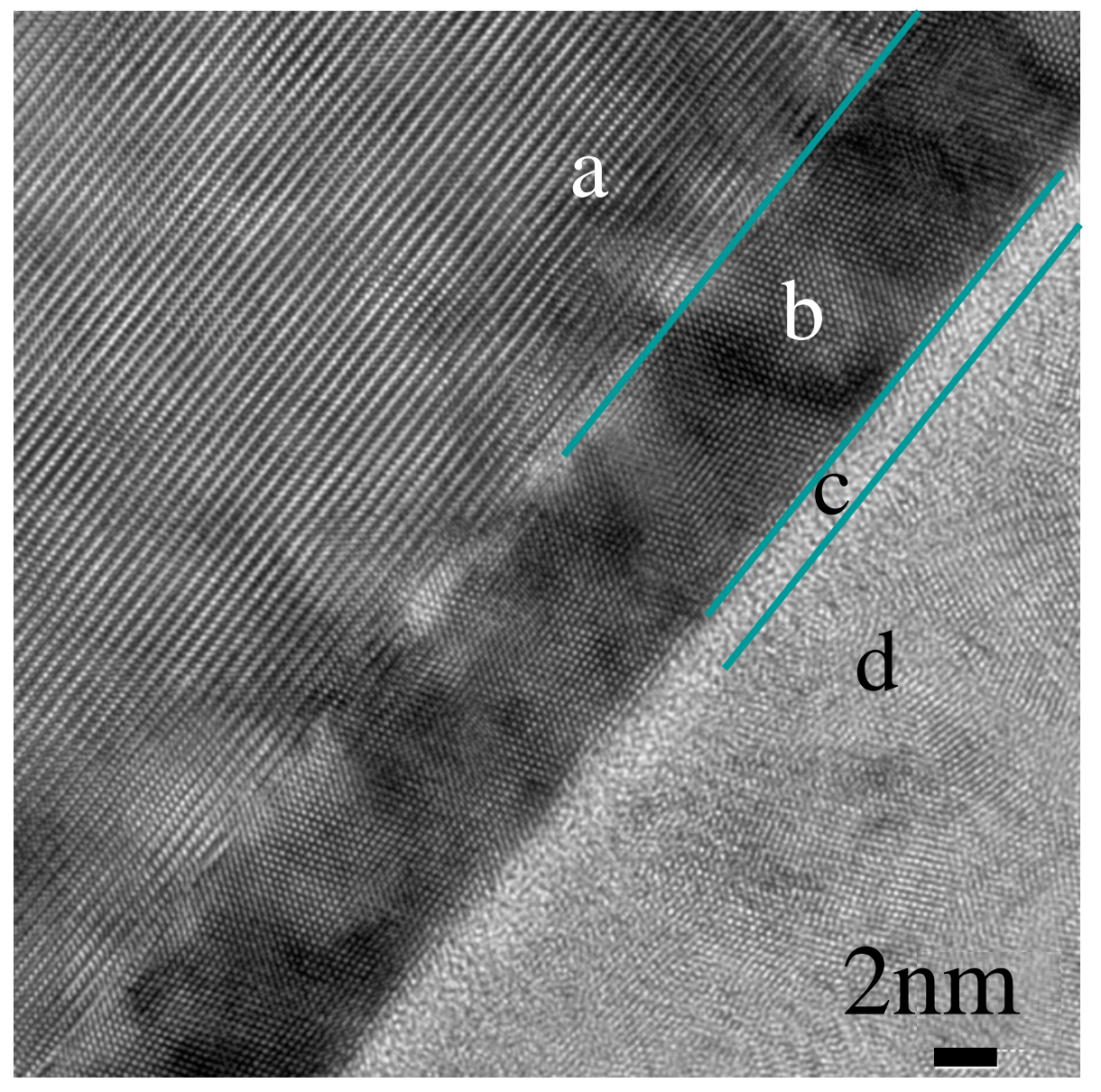

(b) 
Fig. 9

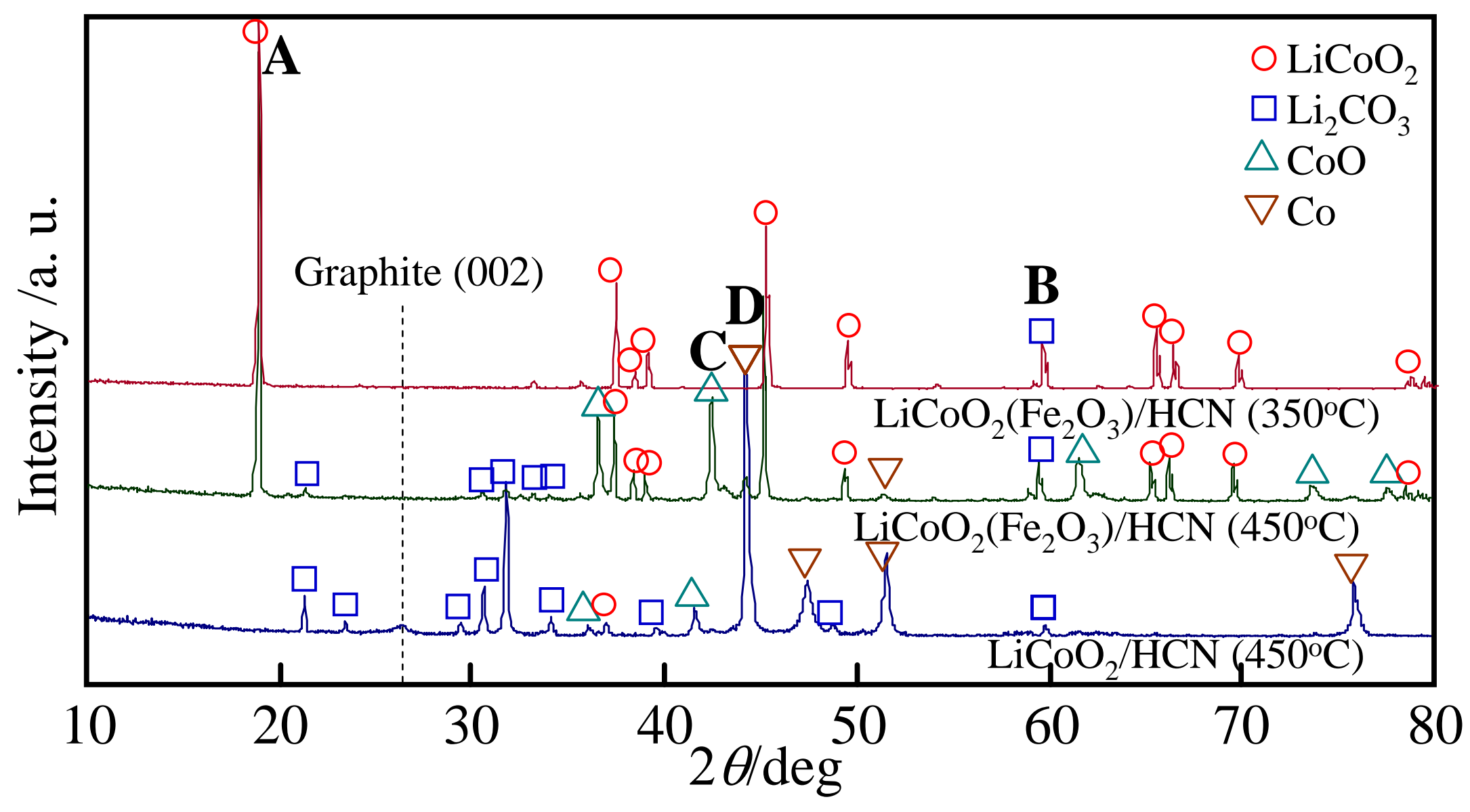


Fig. 10

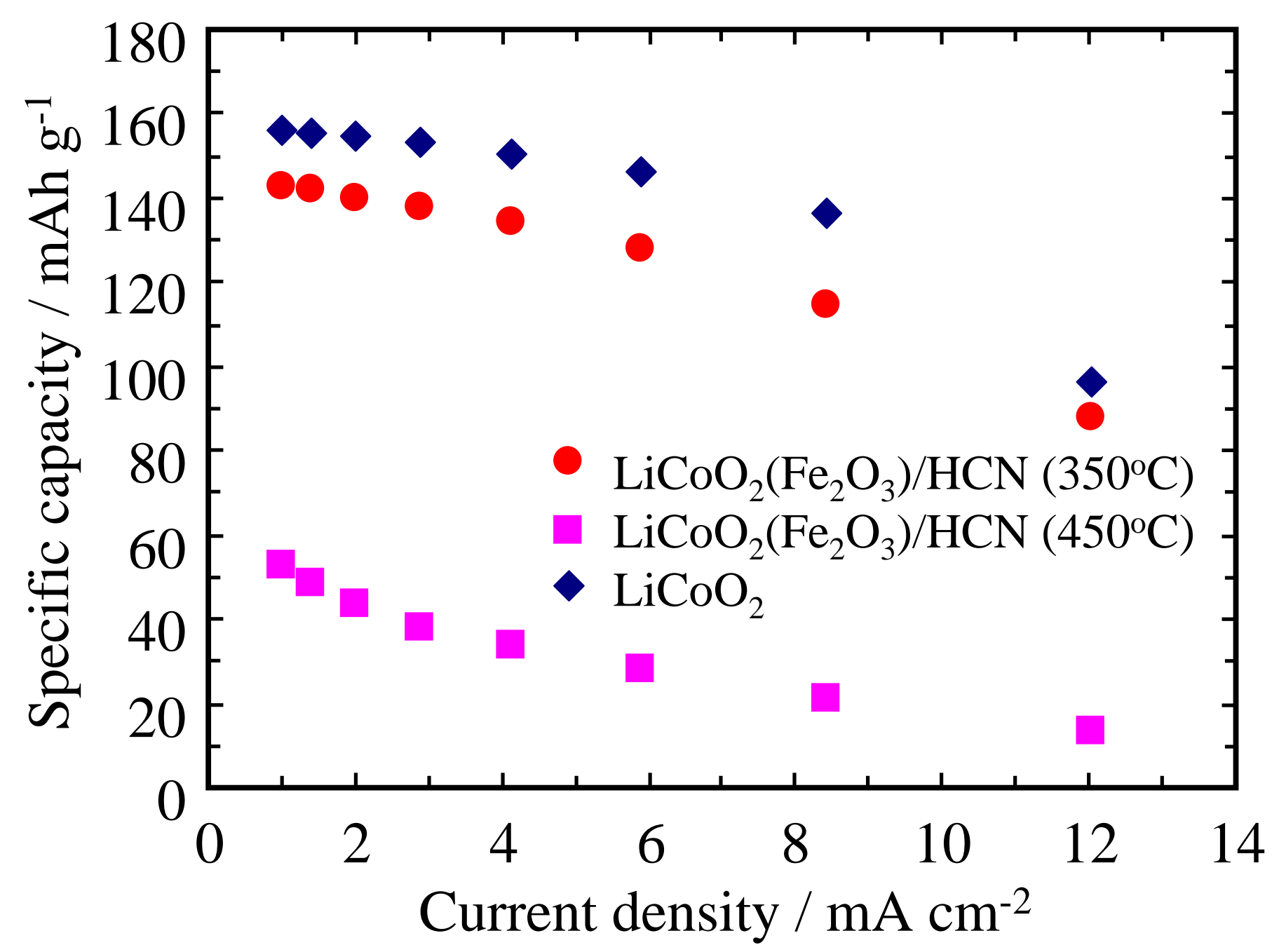


Fig. 11

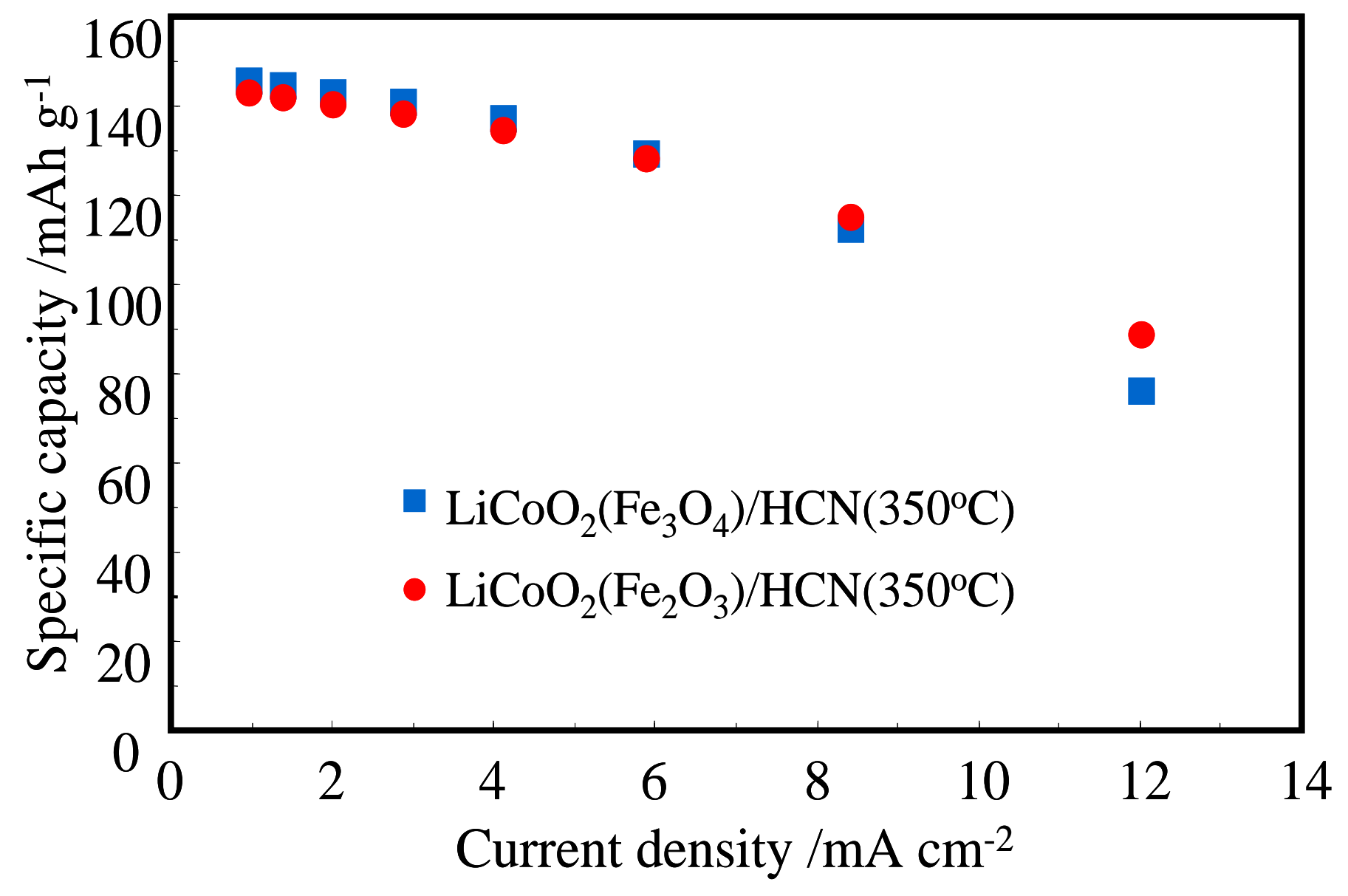

